\title{
The Influence of Transformational Leadership Style on Employee's Performance PT PLN Cabang Pekanbaru Rayon Panam
}

\author{
Astadi Pangarso (Author), Syarifuddin, Mahir Pradana, Nadya Moeliono, Benny M. Fazrido \\ Business Administration Department \\ Telkom University (Tel-U) \\ Bandung, Indonesia \\ astadipangarso@telkomuniversity.ac.id, syarifuddin@telkomuniversity.ac.id, \\ mahirpradana@telkomuniversity.ac.id, nadyamoeliono@telkomuniversity.ac.id, fazridobeni@gmail.com
}

\begin{abstract}
This study aimed to determine how much influence of transformational leadership style in influencing employee performance at PT PLN branch Pekanbaru Rayon Panam, Indonesia; in order to make improvements and innovations continue to develop the organization. The method used in this research is quantitative research methods using simple regression analysis. Variable transformational leadership has a positive influence on employee performance at PT PLN branch Pekanbaru Rayon Panam, and the influence is significant. The overall effect of transformational leadership on employee performance at PT PLN branch Pekanbaru Rayon Panam is $22 \%$, and the $78 \%$ rest of it influenced by other variables outside of this research.
\end{abstract}

\section{Keywords: Transformational Leadership, Work Performance}

\section{INTRODUCTION}

The organization is social unity or entity that consciously coordinate works on the basis of continuously relative to fulfill a common goal and or group of goals (Pangarso, 2014). The success of organizations affected by the performance, for every company, would strive to improve the performance of employees in achieving organizational goals that have been set. The performance of employees in the organization leads to the employee's ability to carry out the overall duties of responsibility. These tasks are usually based on indicators of success indicators that have been defined. Several previous types of research on the performance become background to be part of this study (Pangarso, $\left.2014^{\mathrm{a}, \mathrm{b}, \mathrm{c}} ; 2015\right)$.

The object of research that will be examined is PT PLN branch Rayon Panam Pekanbaru. The company serves as a source of electrical power for the need of society, especially the Panam and surrounding communities. It is unique due to the specific topic of human capital and organization of state-owned enterprises in the field of energy in Indonesia. Related researchers in this field are still limited.

Based on data obtained on the performance of employees of PT PLN branch Pekanbaru Rayon Panam in 2014 and 2015, it can be seen there is still a drop in performance. It can be seen in the indicators of customer perspective, which at the increasing number of achievements in 2014 reached $106 \%$ but fell to $66 \%$ in 2015 . And the total percentage decline which was originally $78 \%$ in 2014 to $72 \%$ in 2015 . This study aimed to determine how much influence transformational leadership style in influencing employee performance at PT PLN branch Pekanbaru Rayon Panam, Indonesia in order to make improvements and innovations continue to develop the organization.

From some research on the topic of leadership, it is still quite interesting to observe this topic (Almansour, 2012) (Sahgal et.al, 2007) (Chaudhry et.al, 2012) (Bass et al, 2003) 
(Bryman, 2007) (Sinambela, 2012). Employees can survive in a company if they feel comfortable and happy to work in the company. A sense of comfort and pleasure brought on by various factors in the company one of which is the leadership style. Leadership styles used by a leader can affect the performance of an organization. According to Bangun (2012), a leader will be able to influence the performance of an organization, depending on how he's doing leadership activities therein. 


\section{LITERATURE REVIEW}

Table 1

Journal Articles

\begin{tabular}{|c|c|c|c|c|c|c|}
\hline No & Research Title & Researcher & Variables & $\begin{array}{l}\text { Research } \\
\text { Objectives }\end{array}$ & $\begin{array}{l}\text { Similarity \& } \\
\text { Difference }\end{array}$ & Results \\
\hline 1 & $\begin{array}{l}\text { The Relationship } \\
\text { Between Leadership } \\
\text { Styles and } \\
\text { Motivation of } \\
\text { Managers } \\
\text { Conceptual } \\
\text { Framework }\end{array}$ & $\begin{array}{l}\text { Dr. Yaser } \\
\text { Mansour } \\
\text { Almansour } \\
(2012)\end{array}$ & $\begin{array}{l}\text { Independent } \\
\text { Variable }(\mathrm{X}) \\
\mathrm{X} 1 \text { : leadership } \\
\text { styles } \\
\\
\text { Dependent } \\
\text { Variable (Y) } \\
\mathrm{Y} 1 \text { : motivation }\end{array}$ & $\begin{array}{l}\text { To find out } \\
\text { whether there is a } \\
\text { significant } \\
\text { relationship } \\
\text { between } \\
\text { leadership style } \\
\text { and motivation }\end{array}$ & $\begin{array}{l}\text { Similarity: } \\
\text { Both use simple } \\
\text { linear regression } \\
\text { analysis } \\
\text { Difference: } \\
\text { Using a mixed } \\
\text { approach from } \\
\text { descriptive and } \\
\text { exploratory } \\
\text { approaches. }\end{array}$ & $\begin{array}{l}\text { Transformation } \\
\text { al and } \\
\text { transformation } \\
\text { al leadership } \\
\text { styles play an } \\
\text { important role } \\
\text { in the } \\
\text { organization } \\
\text { and can form } \\
\text { more } \\
\text { productive } \\
\text { individuals }\end{array}$ \\
\hline 2 & $\begin{array}{l}\text { Transformational } \\
\text { Leader: Their } \\
\text { Socialization, Self- } \\
\text { Concept, and } \\
\text { Shaping } \\
\text { Experiences }\end{array}$ & $\begin{array}{l}\text { Punam } \\
\text { Sahgal dan } \\
\text { Anil Pathlak } \\
(2014)\end{array}$ & $\begin{array}{l}\text { Independent } \\
\text { Variable }(\mathrm{X}) \\
\mathrm{X} 1 \text { : } \\
\text { transformational } \\
\text { leader } \\
\\
\text { Dependent } \\
\text { Variable }(\mathrm{Y})\end{array}$ & $\begin{array}{l}\text { This study was } \\
\text { conducted to } \\
\text { determine the } \\
\text { impact of } \\
\text { transformational } \\
\text { leadership on the } \\
\text { socialization, and } \\
\text { self-concept, and } \\
\text { shaping } \\
\text { experiences }\end{array}$ & $\begin{array}{l}\text { Similarity: } \\
\text { Equally using } \\
\text { transformational } \\
\text { leadership as } \\
\text { independent } \\
\text { variables, using } \\
\text { simple linear } \\
\text { regression analysis }\end{array}$ & $\begin{array}{l}\text { In this } \\
\text { research can } \\
\text { be obtained } \\
\text { the result that } \\
\text { a leader can } \\
\text { be developed. } \\
\text { Life } \\
\text { experiences } \\
\text { play a role that } \\
\text { is important in }\end{array}$ \\
\hline
\end{tabular}




\begin{tabular}{|c|c|c|c|c|c|c|}
\hline & & & $\begin{array}{l}\text { Y1: self- } \\
\text { concept, } \\
\text { shaping } \\
\text { experiences }\end{array}$ & & $\begin{array}{l}\text { Difference: } \\
\text { Data obtained from } \\
\text { interview }\end{array}$ & $\begin{array}{l}\text { building } \\
\text { capabilities } \\
\text { that enable } \\
\text { individuals to } \\
\text { achieve } \\
\text { success. }\end{array}$ \\
\hline 3 & $\begin{array}{l}\text { The impact of } \\
\text { transformational and } \\
\text { transactional } \\
\text { leadership styles on } \\
\text { motivation of } \\
\text { employee in } \\
\text { Pakistan }\end{array}$ & $\begin{array}{l}\text { Abdul } \\
\text { Qayyum } \\
\text { Chaudhry } \\
\text { dan } \\
\text { Munawar } \\
\text { Sabir (2015) }\end{array}$ & $\begin{array}{l}\text { Independent } \\
\text { Variable }(\mathrm{X}) \\
\mathrm{X} 1 \text { : } \\
\text { transformational } \\
\text { leadership } \\
\mathrm{X} 2 \text { : } \\
\text { transactional } \\
\text { leadership } \\
\text { Dependent } \\
\text { Variable }(\mathrm{Y}) \\
\mathrm{Y} 1 \text { : motivation }\end{array}$ & $\begin{array}{l}\text { To find out } \\
\text { whether there is a } \\
\text { significant effect } \\
\text { of } \\
\text { transformational } \\
\text { and transactional } \\
\text { leadership styles } \\
\text { on motivation }\end{array}$ & $\begin{array}{l}\text { Similarity: } \\
\text { Both use } \\
\text { transformational } \\
\text { leadership as } \\
\text { independent } \\
\text { variables } \\
\text { Difference: } \\
\text { Using multiple linear } \\
\text { regression analysis }\end{array}$ & $\begin{array}{l}\text { The results } \\
\text { showed a } \\
\text { positive and } \\
\text { significant } \\
\text { relationship } \\
\text { between } \\
\text { independent } \\
\text { variables } \\
\text { transformation } \\
\text { al leadership } \\
\text { and } \\
\text { transactional } \\
\text { with } \\
\text { motivation. } \\
\text { And there is a } \\
\text { positive and } \\
\text { significant } \\
\text { relationship } \\
\text { between } \\
\text { transformation } \\
\text { al leadership } \\
\text { and motivation }\end{array}$ \\
\hline 4 & $\begin{array}{l}\text { Unit Performance by } \\
\text { Assessing } \\
\text { Transformational } \\
\text { and Transactional } \\
\text { Leadership }\end{array}$ & $\begin{array}{l}\text { Bernard M. } \\
\text { Bass, Bruce } \\
\text { J. Avolio, } \\
\text { dan Yair } \\
\text { Berson }\end{array}$ & $\begin{array}{l}\text { Independent } \\
\text { Variable (X) } \\
\text { X1:- }\end{array}$ & $\begin{array}{l}\text { To understand } \\
\text { the performance } \\
\text { unit by applying } \\
\text { transformational } \\
\text { and transactional }\end{array}$ & $\begin{array}{c}\text { Similarity: } \\
-\end{array}$ & $\begin{array}{l}\text { The result of } \\
\text { this study is } \\
\text { that both } \\
\text { leadership } \\
\text { styles are }\end{array}$ \\
\hline
\end{tabular}




\begin{tabular}{|c|c|c|c|c|c|c|}
\hline & & (2012) & $\begin{array}{l}\text { Dependent } \\
\text { Variable }(\mathrm{Y}) \\
\text { Y1 : - }\end{array}$ & leadership styles & $\begin{array}{l}\text { Difference: } \\
\text { Researchers use } \\
\text { MLQ method to } \\
\text { measure the } \\
\text { effectiveness of } \\
\text { leadership style. } \\
\text { This research used } \\
\text { survey technique } \\
\text { with } 72 \\
\text { respondents. }\end{array}$ & $\begin{array}{l}\text { positively } \\
\text { related to the } \\
\text { performance } \\
\text { platoon for } \\
\text { partially } \\
\text { mediated } \\
\text { leadership } \\
\text { through unit- } \\
\text { level potential } \\
\text { and cohesion }\end{array}$ \\
\hline 5 & $\begin{array}{l}\text { Effective Leadership } \\
\text { in Higher Education }\end{array}$ & $\begin{array}{l}\text { Alan } \\
\text { Bryman } \\
\text { (2013) }\end{array}$ & $\begin{array}{l}\text { Independent } \\
\text { Variable }(\mathrm{X}) \\
\mathrm{X} 1 \text { : leadership } \\
\text { Dependent } \\
\text { Variable } t(\mathrm{Y}) \\
\mathrm{Y} 1 \text { : - }\end{array}$ & $\begin{array}{l}\text { To figure out } \\
\text { effective } \\
\text { implementation of } \\
\text { the leadership }\end{array}$ & $\begin{array}{l}\text { Similarity: } \\
\text { Both use } \\
\text { transformational } \\
\text { leadership as } \\
\text { independent } \\
\text { variables }\end{array}$ & $\begin{array}{l}\text { The results of } \\
\text { this study are } \\
\text { leadership } \\
\text { behaviors } \\
\text { associated } \\
\text { with } \\
\text { effectiveness } \\
\text { in higher } \\
\text { education. The } \\
\text { conclusion of } \\
\text { this research is } \\
\text { that } \\
\text { management } \\
\text { and } \\
\text { leadership, } \\
\text { either } \\
\text { structurally or } \\
\text { semi- } \\
\text { structured, can } \\
\text { be said to be } \\
\text { effective, } \\
\text { because it has } \\
\text { the main goal }\end{array}$ \\
\hline
\end{tabular}




\begin{tabular}{|l|l|l|l|l|}
\hline & & & & $\begin{array}{l}\text { is the } \\
\text { achievement } \\
\text { of vision- } \\
\text { mission } \\
\text { organization }\end{array}$ \\
\hline
\end{tabular}


According to Suriasumantri in Sugiyono (2014), a researcher must use scientific theories as for the basis for argumentation in constructing a hypothetical framework. This frame of mind is a temporary explanation of the symptoms that are the object of the problem. The framework of thinking in this study is the influence of leadership style on employee performance.

In the workplace of an employee associated with many people, it takes the leader figure as a controller both organizational and personal. Basically, leadership is one of the strategic management functions, because leadership can move, empower, and direct resources effectively and efficiently towards the achievement of goals (Soekarso, 2010). For this, there are many strategies that can be done, one of which is by applying the transformational leadership dimension that leaders use to their subordinates. The dimensions proposed by Bass dan Avolio (as quoted in Northouse, 2013) are as follows:

1. Idealized Influence, Describes a leader who acts as a powerful example for followers. Followers associate themselves with this leader and are eager to imitate them. These leaders usually have very high standards of ethical morals and behavior and can be relied upon to do the right thing. They are greatly appreciated by followers who usually strongly believe in them.

2. Inspirational Motivation, Describe leaders who communicate high expectations to followers, inspire them through motivation to be true to, or be part of a shared vision within the organization. Team spirit is enhanced by this type of leadership. They make it through encouraging words and short conversations, to give a clear spirit to communicate the important role they play in the future growth of the company.

3. Intelectual Stimulation, it includes creative and innovative followers' stimulation and stimulates their own beliefs and values, as well as the values and beliefs of leaders and organizations. These leadership journals support followers when trying new approaches and developing innovative ways of dealing with organizational problems. It encourages employees to think things through independently and engage in careful decision making.

4. Individualized Consideration, These factors represent leaders who provide a supportive climate, where they listen carefully to the needs of each follower. Leaders act as coaches and advisors while trying to help followers actually get what they want.

In this study, the researchers used the theory of Bass \& Avolio to determine the dimensions that will be the frame of thought in this study. The reason for using Bass \& Avolio theory is that transformational leadership is part of the "new leadership" paradigm, then Bass \& Avolio first developed broader transformational leadership and improved the previous transformational leadership theory proposed by Burns (1978). Bass \& Avolio developed transformational leadership theory that cares about improving follower performance and maximizing potential followers. The dimensions put forward by Bass \& Avolio include ideal influences, inspiring motivation, intellectual stimulation, and personal considerations.

John Milner as quoted by Sudarmanto (2011) suggests 4 dimensions that can be used as a benchmark in assessing performance, which are:

\section{Quality}

Describes the level of error, damage, and accuracy. Quality of work will result in the quality of work based on established standards. Quality of work can be measured with indicators of accuracy, accuracy, skills and work success. Quality of work includes accuracy, thoroughness, tidiness, and cleanliness of the work.

2. Quantity

3. The size of the quantity is the amount of work produced. The number of workers in accordance with the existing working time. Noteworthy is not the routine result but how fast the work can be completed. The quantity of work includes output, as well as not only the routine output but also how quickly it can accomplish extra work 
4. Worktime Usage

It is related to the time required to complete the activity or the time required to produce the goods and services. Indicators include the level of absence, delay, effective working time/hours lost work.

5. Cooperating with others in workplace

This involves the ability to work with others in completing group tasks. A person may appear more likely to decrease or improve his performance in group assignment contributions.

In this study, researchers used the theory of John Milner as quoted by Sudarmanto (2011) Because researchers believe that the performance dimensions proposed by John Milner can be a benchmark standard in assessing performance. John Milner's theory covers the output of work and individual behavior aspects. This means that John Milner's theory is so dense, clear and effective that summarized in some dimension of performance appraisal in an organization rather than the theory put forward by other researchers. With the elaboration of theory and indicators taken from various angles that are summarized in several aspects make researchers more confident using John Milner's theory in Sudarmanto (2011). follows:

Based on the description of the theories above, then made the frame of thought as

\begin{tabular}{|l|l|}
\hline \multicolumn{1}{|c|}{ Transformational Leadership } \\
1. Idealized Influence \\
2. Inspirational \\
Motivation \\
3. Intellectual \\
\\
Stimulation \\
4. Individualized \\
Consideration \\
Bass dan Avolio \\
\hline
\end{tabular}

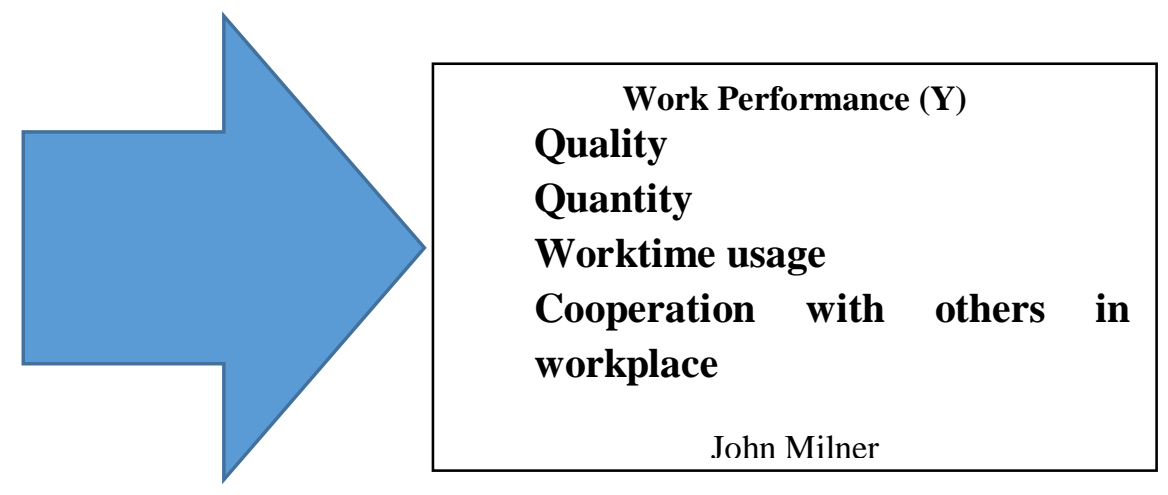

Figure 1. Model hypotheses

Bangun (2012) argued that Which says that leadership styles applied by a leader can affect performance within an organization. This was also reinforced by previous research results from Yudha (2014), States that there is a relationship between transformational leadership to performance, where the transformational leadership dimension of idealized influence, inspirational motivation, and individual consideration has a positive and significant influence simultaneously on performance. Therefore, the hypothesis of this study is "Transformational Leadership Style Influence On Employee Performance On PT. PLN Pekanbaru Rayon Panam."

\section{METHODOLOGY}

The approach used in this study is a causal quantitative method. The measurement scale used in this research is ordinal scale using Likert scale method. The population in this study are employees of PT. PLN Pekanbaru Rayon Panam. The employees taken as respondents were 38 persons. Sampling technique in this research is done by using nonprobability sampling as written in Sugiyono (2011: 66). nonprobability sampling is a sampling technique that does not provide equal opportunities/opportunities for each element or member of the population to be selected to be sampled. The nonprobability sampling technique is saturated sample. Saturated samples are sampling techniques when all members of the population are used as samples (Sugiyono, 2011:68). Thus, the number 
of samples used for this study is the total population or number of employees PT. PLN Pekanbaru Rayon Panam were 38 employees.

Table 2

Operational Variables

\begin{tabular}{|c|c|c|c|}
\hline Variables & $\begin{array}{c}\text { Sub- } \\
\text { Variables }\end{array}$ & Indicators & Items \\
\hline \multirow{8}{*}{$\begin{array}{c}\text { Transformational Leadership } \\
(\mathbf{X}) \\
\text { The effect of transformational } \\
\text { leadership as leaders or superiors to } \\
\text { subordinates. Subordinates feel the } \\
\text { confidence, pride, loyalty, and respect } \\
\text { to superiors, and they are motivated to } \\
\text { perform beyond what is expected inside } \\
\text { the work unit. } \\
\text { Source: Bass \& Avolio }\end{array}$} & \multirow{5}{*}{$\begin{array}{l}\text { Idealized } \\
\text { Influence }\end{array}$} & $\begin{array}{c}\text { The leader } \\
\text { acts as a role } \\
\text { model }\end{array}$ & 1 \\
\hline & & $\begin{array}{l}\text { Acting by } \\
\text { growing } \\
\text { respect } \\
\text { subordinate } \\
\text { to } \\
\text { himself/herse } \\
\text { If }\end{array}$ & 2 \\
\hline & & $\begin{array}{c}\text { Consider the } \\
\text { moral } \\
\text { responsibility } \\
\text { in making } \\
\text { decisions }\end{array}$ & 3 \\
\hline & & $\begin{array}{l}\text { Explaining } \\
\text { the } \\
\text { importance } \\
\text { of work } \\
\text { targets }\end{array}$ & 4 \\
\hline & & $\begin{array}{l}\text { Giving } \\
\text { priority to the } \\
\text { common } \\
\text { interest }\end{array}$ & 5 \\
\hline & \multirow{3}{*}{$\begin{array}{c}\text { Inspiratio } \\
\text { nal } \\
\text { Motivatio } \\
n\end{array}$} & $\begin{array}{c}\text { Talking about } \\
\text { the } \\
\text { organization' } \\
\text { s future with } \\
\text { optimism }\end{array}$ & 6 \\
\hline & & $\begin{array}{c}\text { The } \\
\text { importance } \\
\text { of the vision } \\
\text { and mission } \\
\text { of the } \\
\text { organization }\end{array}$ & 7 \\
\hline & & $\begin{array}{c}\text { Showed } \\
\text { confidence } \\
\text { that the work } \\
\text { objective has } \\
\text { been set to } \\
\text { be achieved }\end{array}$ & 8 \\
\hline
\end{tabular}




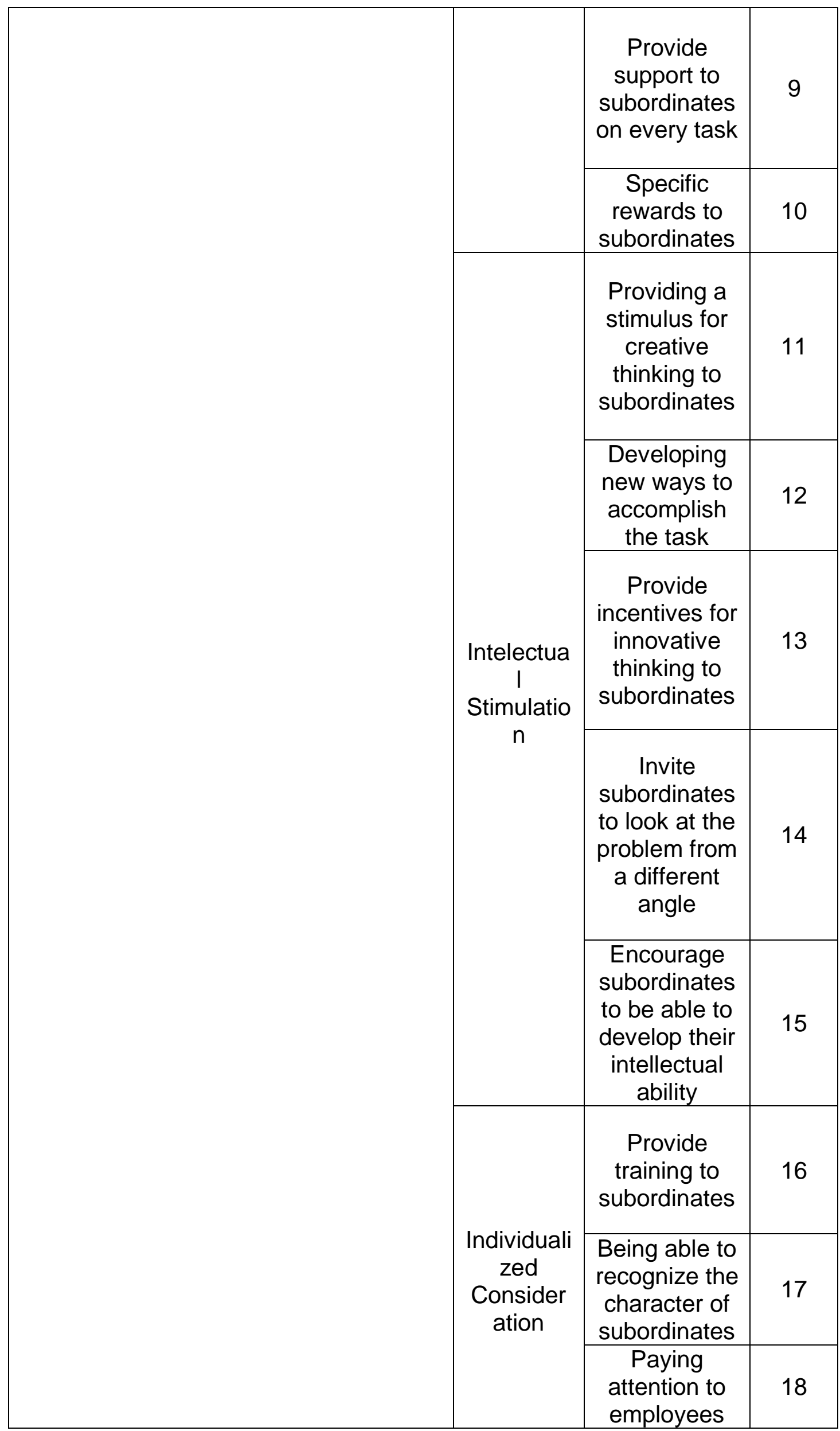




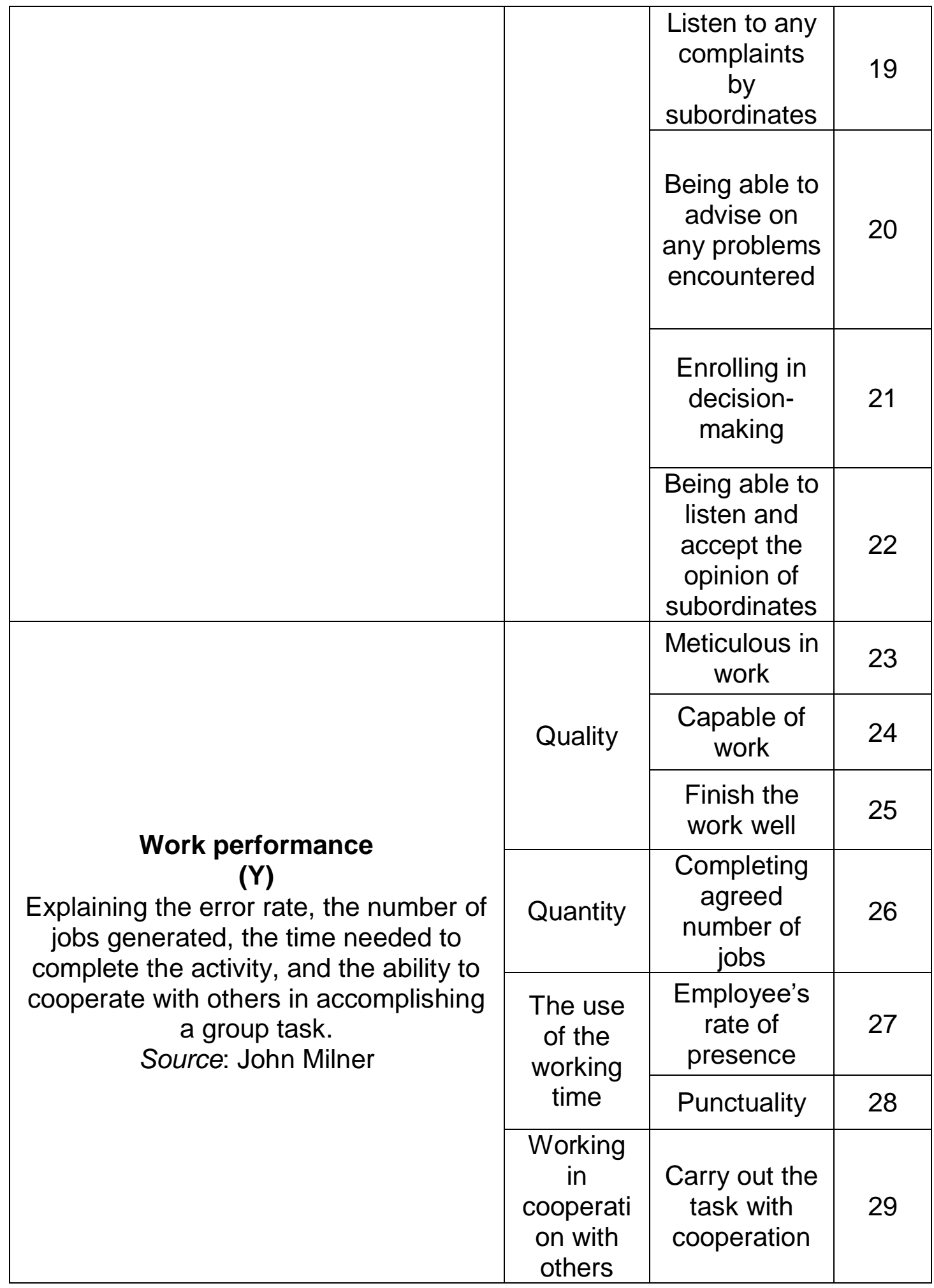

Table 3

Validity Test

\begin{tabular}{|c|c|c|c|c|}
\hline Sub Variables & Statement & $\begin{array}{c}\mathbf{r} \\
\text { table }\end{array}$ & $\begin{array}{c}\mathbf{r} \\
\text { calculation }\end{array}$ & Conclusion \\
\hline \multirow{3}{*}{$\begin{array}{c}\text { (Idealized } \\
\text { Influence) }\end{array}$} & 1 & 0,361 & 0,514 & Valid \\
\cline { 2 - 5 } & 2 & 0,361 & 0,438 & Valid \\
\cline { 2 - 5 } & 3 & 0,361 & 0,606 & Valid \\
\cline { 2 - 5 } & 4 & 0,361 & 0,725 & Valid \\
\hline
\end{tabular}




\begin{tabular}{|c|c|c|c|c|}
\hline & 5 & 0,361 & 0,779 & Valid \\
\hline \multirow{4}{*}{$\begin{array}{c}\text { (Inspirational } \\
\text { Motivation) }\end{array}$} & 6 & 0,361 & 0,549 & Valid \\
\cline { 2 - 5 } & 7 & 0,361 & 0,463 & Valid \\
\cline { 2 - 5 } & 8 & 0,361 & 0,673 & Valid \\
\cline { 2 - 5 } & 9 & 0,361 & 0,829 & Valid \\
\hline \multirow{4}{*}{ (Intellectual } & 11 & 0,361 & 0,777 & Valid \\
\cline { 2 - 5 } Stimulation) & 12 & 0,361 & 0,741 & Valid \\
\cline { 2 - 5 } & 13 & 0,361 & 0,768 & Valid \\
\cline { 2 - 5 } & 14 & 0,361 & 0,721 & Valid \\
\hline \multirow{4}{*}{ (Individual } & 15 & 0,361 & 0,817 & Valid \\
\cline { 2 - 5 } & 16 & 0,361 & 0,845 & Valid \\
\cline { 2 - 5 } & 17 & 0,361 & 0,747 & Valid \\
\cline { 2 - 5 } & 19 & 0,361 & 0,741 & Valid \\
\cline { 2 - 5 } & 20 & 0,361 & 0,772 & Valid \\
\cline { 2 - 5 } & 21 & 0,361 & 0,601 & Valid \\
\cline { 2 - 5 } & 22 & 0,361 & 0,817 & Valid \\
\hline
\end{tabular}

\begin{tabular}{|c|c|c|c|c|}
\hline $\begin{array}{c}\text { Sub } \\
\text { Variables }\end{array}$ & Statement & $\begin{array}{c}\mathbf{r} \\
\text { table }\end{array}$ & $\begin{array}{c}\mathbf{r} \\
\text { calculation }\end{array}$ & Conclusion \\
\hline \multirow{4}{*}{ Employee } & 23 & 0,361 & 0,705 & Valid \\
\cline { 2 - 5 } performance & 24 & 0,361 & 0,720 & Valid \\
\cline { 2 - 5 } & 25 & 0,361 & 0,402 & Valid \\
\cline { 2 - 5 } & 26 & 0,361 & 0,634 & Valid \\
\cline { 2 - 5 } & 27 & 0,361 & 0,472 & Valid \\
\cline { 2 - 5 } & 28 & 0,361 & 0,505 & Valid \\
\cline { 2 - 5 } & 29 & 0,361 & 0,671 & Valid \\
\hline
\end{tabular}

Table 4

reliability test

\begin{tabular}{|c|c|c|c|c|}
\hline Variables & $\begin{array}{l}\mathrm{N} \\
\text { (Sum } \\
\text { Item) }\end{array}$ & 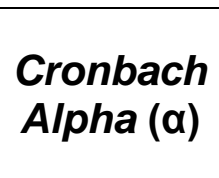 & $\begin{array}{l}\text { Cronbach } \\
\text { Alpha (a) } \\
\text { Variables }\end{array}$ & Conclusion \\
\hline $\begin{array}{l}\text { Transformational } \\
\text { Leadership Style } \\
\text { (X) }\end{array}$ & 21 & 0,60 & 0,958 & Reliable \\
\hline Performance $(\mathrm{Y})$ & 7 & 0,60 & 0,802 & Reliable \\
\hline
\end{tabular}




\section{RESULT AND DISCUSSION}

Normality test to determine whether the dependent variable, independent or both normal distribution, close to normal or not. A good regression model should be normally distributed or near normal. Whether the data was normally distributed or not, can be known by describing the spread of data through the graph. If it spreads around the diagonal line and follows the direction of the diagonal line, the regression model satisfies the assumption of normality (Umar, 2008). This research uses graph method P-P plot with the help of SPSS software. We can see the result below:

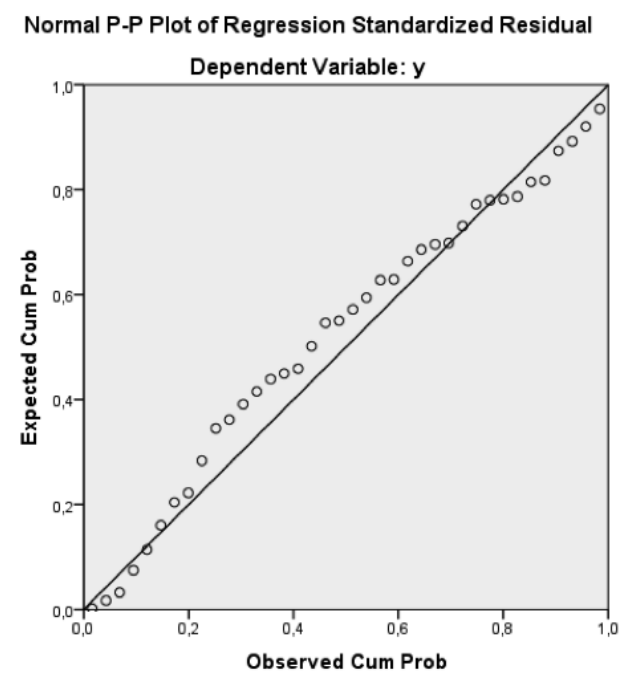

Figure 2 Normal P-P Plot of Regression Standardized Residual

According to Sunjoyo et al (2013), The heteroscedasticity test was performed to determine whether, in a regression model, the residual variant was not the same in all observations. A good regression model is no heteroscedasticity. The method used to test heteroscedasticity in this research is to see the scatterplot chart with the basis of the decision is as follows:

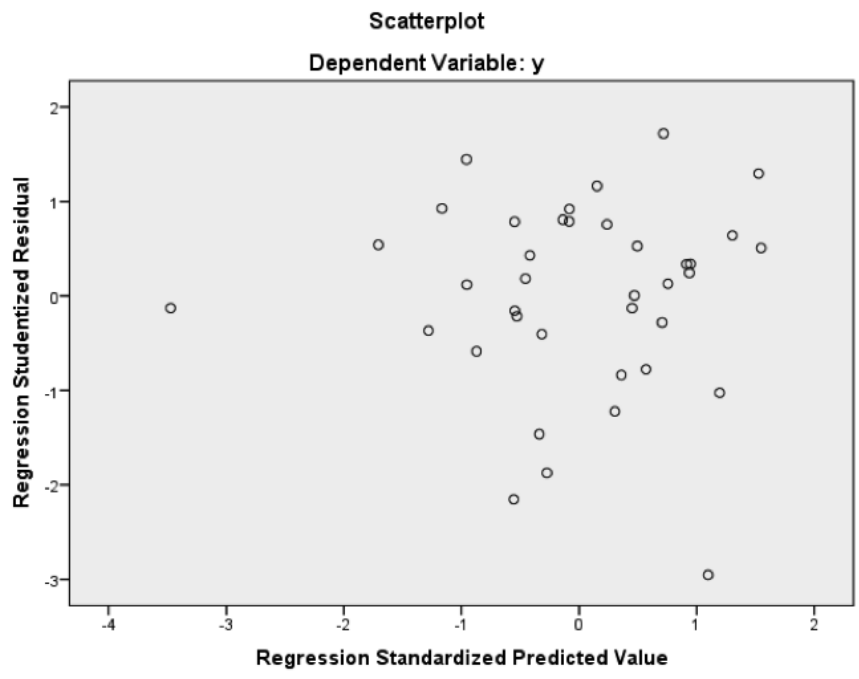

Figure 3 Scatterplot

1. When the distribution of data is scattered around the numbers 0 (zero) on the y-axis, Either above or below, there is no heteroscedasticity.

2. When the distribution of a pattern or trend of a particular line, then heteroscedasticity occurs. 
Based on the analysis in Figure 4.8 above, it can be seen that the residual form of the points contained in the scatterplot graph spread without forming a particular pattern. Therefore, it can be seen that the scatter diagram does not form a certain pattern then the regression does not experience interference heteroscedasticity. Thus the data obtained is normally distributed and the data used in this study has passed the test in normality, which means that for the regression test to be performed by the researcher can be continued and has been eligible,

Table 5

Simple Regression test Result

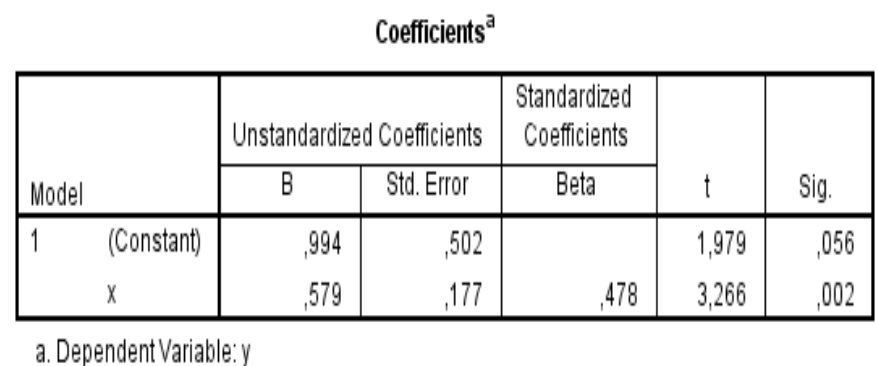

Data management is a simple linear regression, therefore obtained from the following equation:

$Y=a+b X$

$Y=0,994+0,579 X$

From the equation above can be obtained that, Constant value a $(0,994)$ means that when the value of $X$ (transformational leadership style) is 0 then the value of $Y$ (performance) is 0,994 , while regression coefficient of $b(0,579)$ means that every one level of $X$ goes up, then $Y$ will also increase in the value of 0,579 .

\section{Table 6}

T-Test Result

Coefficients $^{\mathrm{a}}$

\begin{tabular}{|c|c|c|c|c|c|c|}
\hline \multirow{2}{*}{\multicolumn{2}{|c|}{ Model }} & \multicolumn{2}{|c|}{ Unstandardized Coefficients } & \multirow{2}{*}{$\begin{array}{c}\text { Standardized } \\
\text { Coefficients } \\
\text { Beta }\end{array}$} & \multirow[b]{2}{*}{$t$} & \multirow[b]{2}{*}{ Sig. } \\
\hline & & $B$ & Std. Error & & & \\
\hline & (Constant) & 994 &, 502 & & 1,979 & .056 \\
\hline & $\mathrm{x}$ & .579 & 177 & .478 & 3,266 &, 002 \\
\hline
\end{tabular}

According to the table above, it was found that $t$ calculate value is 3,266 . while $t$ table for $\mathrm{df}=36$ at significant value $5 \%$ or 0,05 is 1,688 . Because $t$ calculate $(3,266)$ is bigger than $t$ table $(1,688)$, we can conclude that $\mathrm{HO}$ is rejected $(\mathrm{H} 1$ is accepted). Overall, transformational leadership style has an influence on employee performance at PT PLN branch Pekanbaru Rayon Panam and the influence is significant. This is in accordance with the theory that has been proposed by John Milner in Sudarmanto (2011: 32) which explains that "leadership is a crucial dimension of competence on the performance or success of an organization." Employee conditions at PT PLN Pekanbaru Rayon Panam have great respect for their leaders because the leadership acts as an example in which it fosters employee respect for him, and this has an impact on the results of their performance. 
Table 7

Determination Coefficient

Model Summary
\begin{tabular}{|l|c|c|c|c|}
\hline Model & R & R Square & $\begin{array}{c}\text { Adjusted R } \\
\text { Square }\end{array}$ & $\begin{array}{c}\text { Std. Error of } \\
\text { the Estimate }\end{array}$ \\
\hline 1 &, $478^{\text {a }}$ &, 229 &, 207 &, 3210982 \\
\hline
\end{tabular}
a. Predictors: (Constant), $x$
b. Dependent Variable: $y$

The effect of transformational leadership style on employee performance of PT PLN branch amounted to Pekanbaru Rayon Panam is $22 \%$. While the rest, which is $78 \%$ influenced by other variables outside this research. The high or low level of performance can be caused by several factors put forward by John Milner in Sudarmanto (2011:30) Namely job motivation, job satisfaction, job design, commitment, leadership participation, management functions, clarity of career direction, competence, organizational culture and many others. Thus the performance is not yet stable at PT PLN Pekanbaru Rayon Panam can be caused by other factors such as work motivation, job satisfaction, job design, commitment, management functions, career clarity, competence and organizational culture not discussed by the researcher.

\section{CONCLUSION}

From the results of hypothesis testing that has been done by the researchers that $\mathrm{H} 1$ was accepted. This means that transformational leadership style has a positive influence on the performance of employees of PT PLN branch Pekanbaru Rayon Panam and the influence is significant.

Suggestions that can be submitted for further research is that the next researcher can test the influence and level of significance of other variables outside the transformational leadership style such as work motivation, job design, commitment, job satisfaction, compensation, organizational culture, etc. that can affect employee performance PT PLN Pekanbaru Rayon Panam.

\section{References}

[1] Almansour, Yaser Mansour. (2012) "The relationship between leadership styles and motivation of managers conceptual framework." Journal of Arts, Science and Commerce 3.1: 161-166.

[2] Bangun, Wilson. (2012). Manajemen Sumber Daya Manusia. Jakarta: Erlangga.

[3] Bass, Bernard M., et al. (2003) "Predicting unit performance by assessing transformational and transactional leadership." Journal of applied psychology 88.2: 207.

[4] Bryman, Alan. (2007) "Effective leadership in higher education: A literature review." Studies in higher education 32.6: 693-710.

[5] Chaudhry, Abdul Qayyum, Husnain Javed, and Munawar Sabir. (2012) "THE IMPACT OF TRANSFORMATIONS AND TRANSACTIONAL LEADERSHIP STYLES ON THE MOTIVATION OF EMPLOYEES IN PAKISTAN." Pakistan Economic and Social Review: 223-231.

[6] Hasibuan, Malayu S.P. (2010) "Manajemen Sumber Daya Manusia". Jakarta: PT Bumi Aksara..

[7] Marwansyah and Mukaram (2012) "Manajemen Sumber Daya Manusia." Bandung: Pusat Penerbit Administrasi Niaga Politeknik Negeri Bandung. 
[8] Northouse, Peter G. (2013). Kepemimpinan Teori dan Praktik. Jakarta: PT. Indeks.

[9] Pangarso, A., and M. Syafira. (2014) "Dominant Factors Affecting the Performance of Bank Marketing Employees." Research Gate. doi 10.2.1 (2014): 2864-3202.

[10] Pangarso, Astadi, Fransiska Putri Wulansari, and Cut Irna Setiawati. (2015) "The Effect of Financial Incentives on Funding Account Officer's Performance."IICIES.

[11] Pangarso, Astadi. (2014) "Study Title: Effect of Training on Employee Performance at Electronics State Owned Company in Bandung."ETAR 2014.

[12] Pangarso, Astadi. (2014) "Organization's structure based on competing for value approach and merger strategy." Technology, Informatics, Management, Engineering, and Environment (TIME-E), 2014 2nd International Conference on. IEEE,

[13] Sahgal, Punam, and Anil Pathak. (2007) "Transformational leaders: Their socialization, self-concept, and shaping experiences." International Journal of Leadership Studies 2.3: 263-279.

[14] Sinambela, Poltak. Lijan. (2012) “Kinerja Pegawai Teori Pengukuran dan Implikasi”. Yogyakarta: Graha IImu.

[15] Soekarso, Agus Sosro, Iskandar Putong, Cecep Hidayat, Teori Kepemimpinan, Mitra Wacana Media, Jakarta 2010.

[16] Sudarmanto. (2011). Kinerja dan Pengembangan Kompetensi SDM. Yogyakarta: Pustaka Pelajar.

[17] Sugiyono. (2014). Metode Penelitian Kuantitatif Kualitatif dan Kombinasi. Bandung : Alfabeta.

[18] Sunjoyo. (2013). Aplikasi SPSS Untuk Smart Riset. Bandung : Alfabeta.

[19] Sutrisno, Edy. (2012) "Manajemen Sumber Daya Manusia”. Jakarta: Kencana.

[20] Yudha, Muhammad Rezki. (2014). Pengaruh Gaya Kepemimpinan Transformasional Terhadap Kinerja Pegawai Telkom Vision RO Jabar. Skripsi S1 Institut Manajemen Telkom: tidak diterbitkan. 